DOI https://doi.org/10.18551/rjoas.2018-07.30

\title{
THE REGULATION OF CAMPAIGN TOOL USE ON THE IMPLEMENTATION OF DISTRICT HEAD ELECTION IN SIDOARJO REGENCY
}

\author{
Anam Choirul \\ Postgraduate School, Airlangga University, Indonesia \\ E-mail: are6sda07.ca@gmail.com
}

\begin{abstract}
The procurement of campaign tools distributed within same amount for every city or regency, there is no exception for the width of the area whether the city / regency are wide or small one. There is no much problem found on city as the width of it is commonly very limited, it ranges the same as around three to six sub-district. Unfortunately, the problem lies on the regency area, the width ranges around ten sub-districts and even more. This policy seems not fair for the politician as the amount of campaign tools they received are the same as city campaign which has smaller range.
\end{abstract}

\section{KEY WORDS}

Campaign tools, city, regency, sub-districts.

The installation of campaign tools by general election council is aimed to introduce the candidates of the future leader into society, article 28 the regulation of general election council number 7 of 2015 decide:

1. KPU of province/ Aceh KIP and KPU/KIP Regency/City provided the campaign tools from creating to installing the tools which is considered in article 5 act 2 alphabet $\mathrm{C}$.

2. The campaign tools stated in act consist of:

- Baliho / billboard/ videotron, the largest size is about $4 \mathrm{~m} \times 7 \mathrm{~m}$, the amount of them are maximum of 5 for each candidates of regency or city;

- The largest flag is about $5 \mathrm{~m} \times 1,15 \mathrm{~m}$, each candidates could take up to 20 (twenty) pieces for sub-district;

- For banner, the largest size would be $1,5 \mathrm{~m} \times 7 \mathrm{~m}$, the council has provided no more than two pieces for each candidates.

Article 69 alphabet $\mathrm{g}$ Law number 1 of 2015 is about the details of the campaign that should not be prohibited by the candidates; they must not damage or relieve the campaign tools provided by KPU. Then, stated in article 187 act 3 Law number 1 of 2015, it is clearly stated that "every person who is consciously disobey the regulation of campaign of Regent or Mayor which is previously stated in article 69 alphabet $\mathrm{g}$, alphabet $\mathrm{h}$, alphabet $\mathrm{i}$, or alphabet $\mathrm{j}$, will receive criminal judge at least one month or six month at most, or they must pay fine for at least Rp100.000,00 or Rp1.000.000,00 at most".

There are many violations found during the election campaign. In order to reduce the violations, specifically, the violations which result in criminal act, article 152 act 1 Law number 1 of 2015 states "in order to equate the understanding and the procedure of criminal act during the election, the province election investigator, and/or Regency/City investigator, District Police and/or Sub-district police, and/or public prosecutor forms Central Law Enforcement".

Law number 1 of 2015 is supported with Law number 8 of 2015. Eve though it has been fixed, from the experience point of view, simultaneous districts election in 2015 still find some problems. One of the problem is the campaign system, more specifically, it is the campaign tools policy, thus the previous law has been amend into Law number 10 of 2016 .

On previous law, number 8 of 2015, the installation of campaign tools is provided by government. The politician of parties found out that the amount of the campaign tools are too limited. Thus, many of the candidates initiate to pay their own campaign tools as it was prohibited by the Law number 8 of 2015 . 
In Law Number 10 of 2016, the installation of campaign aides is not only funded and implemented by the government but also can be funded and implemented by political parties I candidate pairs. With the permission of candidate pairs to add props campaign then there will be new problems related to campaign props such as design problems, the number and installation. Based on the above description of the author interested to discuss issues related to campaign props.

\section{METHODS OF RESEARCH}

Legal research is the process of discovering the rule of law, legal principles, and legal doctrines to address the legal issues faced. This corresponds to the prescriptive character of jurisprudence. In contrast to research conducted in descriptive scholarship that examines the truth of whether or not a fact is caused by a particular factor, legal research is conducted to generate new arguments, theories or concepts as prescriptions in solving the problems encountered. If on descriptive scholarship the expected answer is true or false, the expected answer in legal research is right, appropriate, inappropriate, or wrong. Thus it can be argued that the results obtained in legal research have contains value.

\section{DISCUSSION OF RESULTS}

\section{Authority of Campaign tools Procurement:}

Campaign tools procurement by general election council. In campaign tools procurement, the regulation has been fully conducted at article 28 about the regulation of general election council number 12 of 2016 which stated that:

Province KPU/ Aceh KIP or KPU/KIP Regency/City provided the campaign tools from creating into the installing process which already stated in article 5 act 3 alphabet $\mathrm{C}$.

The campaign tools considered in act 1 covers:

- Baliho / billboard / videotron, the largest size is about $4 \mathrm{~m} \times 7 \mathrm{~m}$, the amount of them are maximum of 5 for each candidates of regency or city;

- The largest flag is about $5 \mathrm{~m} \times 1,15 \mathrm{~m}$, each candidates could take up to 20 (twenty) pieces for sub-district;

- For banner, the largest size would be $1,5 \mathrm{~m} \times 7 \mathrm{~m}$, the council has provided no more than two pieces for each candidates.

The candidates may enhance their own campaign tools within condition as follow:

- The size of campaign tools must be as same as the size of the campaign tools provided by the general election council of province/ Aceh KIP or KPU/KIP Regency/City;

- The copy of campaign tools must not exceed $150 \%$ of the maximum pieces provided by the general election campaign which is already stated in act 2 .

In determining the maximum number of campaign tools which is considered in act 3 alphabet b, Aceh KIP or KPU/KIP Regency/City must coordinate the idea with the candidates of district head or with the political parties.

Aceh KIP or KPU/KIP Regency/City determine the number of maximum campaign tools as considered in act 4 with approved decision with Aceh KIP or KPU/KIP Regency/City.

The additional campaign tools made by the candidates must be attached with the signed approval from Aceh KIP or KPU/KIP Regency/City.

The payment bill must be attached and sent to Aceh KIP or KPU/KIP Regency/City.

The procurement of campaign tools provided by KPU are distributed within same amount for every city or regency, there is no exception for the width of the area whether the city/regency are wide or small one. There is no much problem found on city as the width of it is commonly very limited, it ranges the same as around three to six sub-district. Unfortunately, the problem lies on the regency area, the width ranges around ten subdistricts and even more. This policy seems not fair for the politician as the amount of campaign tools (APK) they received are the same as city campaign which has smaller range. 
In the Campaign Facilitation arrangement by KPU, the Government should pay attention to the proportional principle. So that, there is a difference between districts / municipalities with a large area compared with small districts / municipalities. Facilitating the procurement of campaign props by the KPU should consider the number of sub-districts and villages in each regency / city, for example for the procurement of baliho at least 1 (one) point in each District is not beaten flat as it has only 5 points in each City District. For Batu City, this number may be considered quite enough and it looks festive because in Batu there are only 3 (sub-districts) but if compared with Sidoarjo regency which has 18 (eighteen) subdistricts, the amount is considered very less, especially when compared with Malang Regency, the number of municipalities are 30 areas. Similarly, for the procurement of the flags and the banners must consider the number of sub-districts and villages existing in the respective districts / municipalities so that it would be fair for the participants of the election.

The Additional Campaign Tools. The duty of general election council to provide campaign tools which is already stated in the regulation of general election council Law number 12 of 2016 is still far from the word ideal. Especially, it is not fair for the city or regency who possesses very vast area. Thus, there must be additional campaign tools for the candidates. So, the societies will able to identify their future leader. This regulation already published in the law number 12 of 2016 article 28 act 3 which stated that the candidates could add their own campaign tools with condition as follow:

- The size of campaign tools must be as same as the size of the campaign tools provided by the general election council of province/ Aceh KIP or KPU/KIP Regency/City;

- The copy of campaign tools must not exceed $150 \%$ of the maximum pieces provided by the general election campaign which is already stated in act 2 .

The focus of the problem is in what extent the KPU could guarantee that the additional campaign tools from the candidates is exactly the same as the policies. Even though, the size or numbers of the campaign tools provided by KPU, it is already stated in the regulation of general election council number 12 of 2016.

There is another problem instead of the design and the size of the campaign tools, it is the time management of the campaign tools from KPU and from the candidates. Both must take place in the same time. the phase of the additional campaign tools from the candidates must keep up with the schedule from the KPU.

The Campaign Tools Procurement Control. in the government system of democracy, the ultimate power must be held by the society, the power is possessed by the general election which is free from any oppression. The development of a country is the thing that is very important to analyse and observe the political act from any legal institutions. Thus, the ultimate idea of the country will be achieved as stated in the opening fundamental constitution law of 1945 (UUD 1945) about civil sovereignty. As logical consequences for Indonesia, the movement is not just merely to observe the change the political behaviour within society in general, but it is also to observe the behaviour change of the elite politics (Alfian, 1981:8).

General election process is the important instrument for democracy country who follow the principle of representation (Moh. Kusnardi, 1983:238).

General election work as the tool to filter "politicus politicus" which will be the representation of society in council. The chosen politicians are considered as the individual or the community who have the ability or mandatory to speak up and act as bigger representation of a group through political parties (Miriam Budiarjo, 2008: 1).

An absolute election is needed by the country who follows the principle of democracy. Indonesia is one of country that follows the principle of democracy. Thus, election is very fundamental for leader change who take place in legislation council. The vision and mission of a country will be achieved by the change of leader acquainted from the general election (Mahfud MD,2009:1)

General election is one media for the society to give their aspiration which is very principal. So that, the implementation of election is very mandatory for the government to guarantee the distribution of civil aspiration based on the schedule of the state. According to 
civil sovereignty, all aspects of the general election system is the ultimate decision of society to choose. It is the violation of human right if government is failed to hold general election without the agreement from society, or the government did not commence any general election (Jimly Asshiddiqie, 2013:416).

All elements of country should participate in general election process to achieve successful election. Started from government, election council, the participants of candidates, an dparticipation of society. Without active participation and coordination of all elements, the election would not run well and effective, for example is the campaign tools provided by KPU and additional campaign tools from the candidates, it must be controlled and observed by the council. Even though the limitation for each campaign tools is already stated in Law number 12 of 2016, in reality, many politicians or supporters of the candidates breaks the rule. In one hand, the number of general election council personnel is way less than the people that they must take care of. That is why, the role and support from society is very useful to prevent such an action. Because, without help of society, KPU will not able to commence perfect election.

From the confusion of campaign tools policy, there must be an agreement and major understanding for every element of participants. In this case, the government, election council, the participants and society, they all have their own role as follow:

- Government as the one who provide law and policies, they must revise the regulation or law which does not yet meet the requirement among society;

- KPU as the procurer of general election must be able to interpret regulation provided by the government, they must arrange the technical procedure based on the law which is more applicative in the field;

- KPU of Regency/city must be able to provide the planning based on the condition of current situation of the area. For example, when they need to measure the APK, KPU of Regency/city could not determine their decision only in the aspect of satisfaction; they must consider another aspect such as geographic, situation, and condition of sub-district or village;

- The election investigator must be fair at their role, they must face every violation without considering the backgrounds of the criminals;

- The participant or candidates of the election must obey the regulation stated on constitution and the regulation of KPU;

- The society must be active to observe the use of campaign tools, the help of society will be very helpful as the number of investigators is very limited. Moreover, the number of campaign tools are so wide that they spread in every village, society must be aware of it. Thus, the election process will be excellent.

The Authority of Campaign Tools Distribution and Installation. The system and procurement of general election always become mass interest among people for the government, thus, the concept of people, by people, and for people must e achieved by using the management and quality of the general election (Gaffar Janedjri, 2012:1).

As we know, the general election is seen by people as arena to form democracy and to replace the old leader with the new or the same as people elect their future leader periodically. General election is important instrument for the country that follows ideology of democracy, general elction is not only a process the implementation civil sovereignty, but it also work as instrument to observe the behaviour change of civil politics and direct periodic leader change. General election is very important for the procurement of Indonesia. The democratic election must be direct, in general, confidential, honest, and equitable. Before the election day, the candidates have several days to promote and campaign their idea to society. Campaign is the act if communication which is held by state. The procurement of campaign is mainly an institution or organisation. The organisation could come from government environment, private sector, or civil society (Antar Venus,2004:9).

Political campaign is the act which is systematic, organised, to promote the candidates to be, chosen as candidate, elected, or re-elected in a formal position (Toni Andrianus,2006: 185-186). 
The act of campaign cover some activities as follow; limited meeting; dialogue and face to face meeting; public debate/open debate between candidates; distribution of campaign tools to the public; installation of campaign tools; mass media advertisement or electronic media; and/or other activities that do not break the regulation of campaign and constitution.

After KPU finish printing all the attributes for the candidates for their campaign, it is mandatory for KPU to distribute for each candidate as suggested in regulation of general election council number 12 of 2016 article 30 act 1 . It stated that general election council of province/ Aceh KIP or KPU/KIP Regency/City distribute the campaign tools to the candidates or their supporting team. The campaign tools must be installed at the location determined by KPU.

Installing campaign tools is the most important phase that need an extra attention from both general election council, the candidates, and the investigators. Because, there are so many violations done by people who brake the regulations from KPU. The violations vary from the number of campaign tools to the invalid locations that must not be an option for the candidates to install them.

The main purpose for campaign tool installation is to introduce the candidates to society. The article 28 about the regulation of general election number 12 of 2016 stated that:

- Province KPU/ Aceh KIP or KPU/KIP Regency/City provided the campaign tools from creating into the installing process which already stated in article 5 act 3 alphabet $\mathrm{C}$.

- The campaign tools considered in act 1 covers:

Baliho / billboard / videotron, the largest size is about $4 \mathrm{~m} \times 7 \mathrm{~m}$, the amount of them are maximum of 5 for each candidates of regency or city;

The largest flag is about $5 \mathrm{~m} \times 1,15 \mathrm{~m}$, each candidates could take up to 20 (twenty) pieces for sub-district;

For banner, the largets size would be $1,5 \mathrm{~m} \times 7 \mathrm{~m}$, the council has provided no more thantwo pieces for each candidates.

If we look closely, the article act 3 , article 28 act 1 , and article 30 act 1 regulation of general election council number 12 of 2016 . There is a blurry future about the authority of campaign tools installation. In article act 3 and article 28 act 1, they state that the installation phase of campaign tools is the authority of KPU. In the other hand, article 30 act 1 states that $\mathrm{KPU}$ distribute/ hand over the campaign tools to the supporting team of each candidate. To prevent different interpretation, the authority of campaign tools installation must be fixed. There are three options whether the authority is given to the KPU, candidates, or both of them.

In this case, the installation authority could follow the local Regulation where the election will be held. As stated in KPU regulation number 12 of 2016 article 30 act 4, it is stated that the installation campaign tools must follow the ethic, aesthetic, cleanness, and the beauty of city or the area of election based on the recent constitution.

From the regulation above, we could assume that the installation of campaign tools must follow and coordinate the policy with local governance. Because, it is common for Regency or City to have their exclusive regulations about the installation of advertisement in public area. For example, in Sidoarjo regency, there is local regulation of Sidoarjo number 7 of 2007 about the procurement of billboard installation policy and Regent regulation number 51 of 2014 about the procedure if billboard installation.

\section{CONCLUSION AND SUGGESTIONS}

Regulation or the protection that regulate about the campaign tools procurement and installation is still not maximum, that is why, there are still many violations during the processes, the violations are broken by political parties member, the candidates of district head, or the supporters of each candidates.

Suggestion. Government as the one who provide law and policies, they must revise the regulation or law which does not yet meet the requirement among society. For example, the procurement of campaign tools does not concern with the wide of the district that hold election. Moreover, the authority of campaign tools installation policy is still not yet complete. 
To prevent different interpretation, the authority of campaign tools installation must be fixed. KPU must arrange the technical procedure based on the law which is more applicative in the field.

\section{REFERENCES}

1. Gaffar Janedjri. Politik Hukum Pemilu, Konstitusi Press, Jakarta, 2012.

2. Jimly Asshiddiqie, Pengantar IImu Hukum Tata Negara, Jakarta, Raja Grafindo Persada, 2013.

3. Moh. Kusnardi dan Harmaili Ibrahim,1983, Pengantar Hukum Tata Negara, Jakarta, Pusat Study Hukum Tata Negara Fakultas Hukum UI.

4. Miriam Budiarjo,2008, Dasar Dasar Ilmu Politik, Jakarta, PT. Gramedia.

5. Moh. Mahfud MD, Politik Hukum Di Indonesia, Jakarta, PT. Raja Grafindo Persada, 2009.

6. Toni Andrianus Pito, SIP. Dkk. Mengenal Teori-Teori Politik Dari Sistem Politik.

7. Sampai Korupsi. Bandung: Penerbit Nuansa, 2006.

8. Venus, Antar, Manajemen Kampanye: Panduan Teoritis dan Praktis dalam Mengefektifkan Kampanye Komunikasi. Cet. ke-4. Bandung. Remaja Rosdakarya, 2004. 